\title{
EFFECTS OF INTERNAL MARKETING ON TURNOVER INTENTION OF FRONTLINE EMPLOYEES IN THE TRAVEL AND TOUR AGENCIES IN SABAH
}

\author{
A. Nointin ${ }^{1 *}$, C. T. B. Chui 2 \\ ${ }^{1}$ Arshad Ayub Graduate Business School, Universiti Teknologi MARA, 88997 Kota Kinabalu, Sabah, \\ Malaysia \\ ${ }^{2}$ Arshad Ayub Graduate Business School, Universiti Teknologi MARA, 40450 Shah Alam, Selangor, \\ Malaysia \\ *an.nointin@gmail.com
}

\begin{abstract}
Travel industry notably the tour agencies as a whole should strengthen its internal marketing practices to ensure frontline employees establish customer service experience. There has been an increasing recognition by researchers globally on the importance of internal marketing in the service industry. Past literatures suggested internal marketing had negative relationship with employee turnover but there is still paucity of studies particularly on the travel and tour agencies. This paper examines the effects of internal marketing on turnover intention among frontline employees in the tour agencies in Sabah. Methodology entails employee survey on tour agencies selected from MATTA Sabah chapter. Analysis using PLS-SEM showed that internal marketing factors had significant negative effect on employee turnover intention. Findings had implications on tour companies' strategies to manage turnover of frontline employees.
\end{abstract}

Keywords: Internal Marketing, Tour Agencies, Employee Turnover, Travel, Frontline Employees

\section{INTRODUCTION}

Tourism is now recognized as one of the fastest and largest growing economic sector in the world for having experienced continued expansion and diversification over the past six decades (UNWTO, 2015). UNWTO Tourism Highlights 2016 reported that the average annual growth of world tourism from 2005 - 2015 has been $3.9 \%$ and international tourist arrivals worldwide are expected to reach 1.8 billion by 2030. In 2015, South East Asia (SEA) had 8.8\% market share of the global tourist arrival equivalent to 104.6 million tourists and 108.3 billion US Dollar in tourism receipts. Of this total, Malaysia has 25.72 million tourists equivalent to $9.2 \%$ market share, the second highest in SEA after Thailand. Malaysia has been ranked the ninth most visited country in the world for years from 2010 to 2013. This has put tourism as a huge sector in Malaysia and recognized as an important contributor to the country's economic development.

One of the key success factors of any tourism business is its manpower. Tourism businesses rely heavily on human factors that are both qualified and skilled. Yet, the major persisting challenge facing the tourism industry is recruiting and retaining qualified and skilled labour force. Employee turnover is one of the major problems in tourism and hospitality industry irrespective of their sector for instance travel agents, hotels and related service providers and it has nearly doubled as compared to other industries (Martin et al., (2006). Saridakis and Cooper (2016) stated that 'retaining talented, educated and skilled personnel can positively affect productivity and performance, improve efficiency, growth and prosperity' of an organisation. An important finding by AlBattat et al. (2014), AlBattat and Som (2013) suggested that employee turnover crises in the hospitality industry is a concern not only at international level but also in Malaysia. High degree of employee turnover is an indicator of instability in an organisation. Kim (2014) suggested that the excessive turnover in the tourism and hospitality industry requires additional research focusing on diverse sectors neglected in current turnover studies. It added that although travel agencies are a vital sector in the tourism and hospitality industry, there has been little attention given to examining turnover 
intention among travel agency employees. This is the first gap that this current study is attempting to address. Kim (2014) which research in Korea was claimed as the first attempt to focus on turnover intention in travel agency employees. Travel agencies and tour operators are key players in the tourism industry and in Malaysia they are recognised as important contributors to the continuous growth and development of the industry in the country. The World Travel and Tourism Council (WTTC) reported that the ability of the travel and tourism sector to deliver a consistently high quality visitor experience is limited by the sector's often-transient labour. Moreover, high employee turnover directly leads to higher costs on recruitment, advertising and training; as well as reduce the return on training and increased the workload of existing staff.

Mobley (1977) had stated that actual turnover started with turnover intention. Turnover intention as like the actual employee turnover can be voluntary or involuntary. It is the voluntary turnover that becomes the concern of organizations. According to Chang and Chang (2007), Chen and Chang (2008), voluntary turnover can be caused by organizational factors (such as salary, promotion, work challenge, better work opportunity and so on) or personal factors (health, retirement, physical move, further study and so on). In the case of Malaysia, AlBattat et al. (2014), AlBattat and Som (2013) suggested to the Malaysian hospitality stakeholders to recognize that poor working condition, low salaries and injustice cause employee dissatisfaction and thus lead them to turnover and change job. Scholars had suggested that implementing internal marketing (IM) practices will increase employee loyalty, thus reducing turnover. Study by Chen and Lin (2013) in a private hospital in Taiwan found that IM practices increase employee loyalty. Chang and Chang (2007), Chen and Chang (2008) who studied the employees of hotels in Taiwan had found negative correlations between IM practices and employee turnover intention. Lombard and Steyn (2015) studied the IM practices of travel agencies in the Western Cape Province of South America towards their employees and their findings suggested that the management of travel agencies to put importance on planning and development of internal practices such as training, promotions, merit offerings, performance bonuses, profit sharing and the participation of employees in management decision making. The concept of IM focuses on employee motivation and satisfaction. Job dissatisfaction forces turnover intention (Kuria et al., 2012; Tracey \& Hinkin, 2008) and employee retention increased with job satisfaction (Richardson \& Butler, 2012).

There has been an increasing recognition by global researchers over the importance of IM in the service industry. Berry and Parasuraman (1992) contended that IM is essential to the success of services marketing, as well as to attract, develop, motivate and retain qualified employees. Joung et al. (2015) found IM practices were good indicators for predicting job satisfaction and organisation commitment of which both will significantly lower employee turnover intention. Despite the growing numbers of literatures on IM in the western countries as well as in some countries in the Middle East and Asia, literatures showed very limited studies done in Malaysia particularly in the travel and tour agencies. This is the second gap that this study is attempting to address. Thus, this current study examines the effects of IM on turnover intention through the creation of job satisfaction. Based on past studies, this study adopted reward system, working condition, internal communication and training to form the IM practices. This study draws on survey data involving 246 frontline employees of travel and tour agencies in Sabah. In the following pages, a brief review of the relevant literatures are given, followed by discussion of the methodology and the outline of the research findings. Towards the end, the study results, their managerial implications and suggestion for future research are discussed.

\section{LITERATURE REVIEW AND HYPOTHESIS DEVELOPMENT \\ Turnover Intention}

Turnover intention or propensity to leave the organisation is a behavioural intention that precedes actual turnover (Brown \& Peterson, 1993). Mobley (1982) defined turnover as "the cessation of membership in an organisation by an individual who received monetary compensation from the 
organisation". Job dissatisfaction can lead an employee to start thinking about quitting. The Mobley Model (Mobley, 1977) illustrates turnover as "a withdrawal decision process in a sequence of several psychological steps that start with evaluation of job, experienced job dissatisfaction, thinking of quitting, evaluation of expected utility of search and cost of quitting, intention to search for alternatives, search for alternatives, evaluation of alternatives, comparison of alternatives versus present job, intention to quit or stay and lastly to quit or to stay.

The worldwide investigation by Watson Wyatt Worldwide reported that $58 \%$ of employees abdicate due to dissatisfying salaries and the rest due to dissatisfaction with the management system and the lack of promotion opportunities; lack of skill training; welfare; working environment; conflict with directors or colleagues. It was therefore suggested that in order to keep talented employees, they should be rewarded appropriately and to include non-financial rewards such as training and development and opportunities for promotion (Chang \& Chang 2007; Chen \& Chang, 2008; Kim, 2014). Kim (2014) reviewed literatures in organisational research, human resource management and the tourism and hospitality industry, identified other important factors of turnover intention include organisational support, supervisor and co-worker support, welfare, job ambiguity, autonomy, compensation, job stress and external causes. In the case of hospitality industry, Faldettam et al. (2013) pointed that the seasonal nature of the hospitality industry was one of the main reason of high turnover along with job dissatisfaction, competitive organisational culture, poor training and development opportunities, wrong management styles, stress and burn out, discrimination at workplace, ad hoc recruitment and selection procedures, among others. In the context of the Malaysian hospitality industry, the literature review by AlBattat and Som (2013) suggested that the high employee turnover rate were normally affected by employee dissatisfaction with the overall work environment, working conditions and wages.

The negative consequences of turnover had often been emphasized though it can be both negative and positive for the individuals and organisations. Positive consequences could possibly be caused by functional turnover, but Dalton et al. (1981) suggested that organisation must attach more importance to dysfunctional turnover. Dysfunctional turnover is when an employee wants to leave but the organization prefers to retain her or him. On the other hand, functional turnover is when an employee wants to leave but the organization is unconcerned. Nevertheless, logically when an employee leave an organisation whether it is a functional and dysfunctional turnover, it causes the management a down-time which could be translated as a cost to the organisation. Moreover, the effect of service employees leaving the organization especially those in the tourism and hospitality industry will not only impact negatively on the management and organisations but also on the quality of services which results in customer dissatisfaction (Sims, 2007).

\section{Job Satisfaction}

Hoppock (1935) defined job satisfaction as "any combination of psychological, physiological and environmental circumstances that cause a person truthfully to say I am satisfied with my job". Job satisfaction as such is influenced by many external factors. According to Hoppock (1935), what affect how the employee feels is something from internal. Locke (1976) provided his definition of job satisfaction as "a positive emotional state that reflects an effective response to the job situation". Spector (1997) said that satisfaction is (simply) the extent to which people enjoy their work. Despite the briefness of the definitions, job satisfaction is a complex construct and there are many types of relationships within the organisation that shape job satisfaction. Job satisfaction affects the behaviour of employees of which in turn will affect the functioning and performance of the organisation, thus it plays very critical roles.

Schermerhorn (2008) had also described job satisfaction as "a positive feeling about one's work and work setting". He further explained that it is "an attitude or emotional response" to one's task as well as to the physical and social condition of the workplace. From the perspective of Herzberg's two-factor theory, Schermerhorn (2008) stated that some aspect of job satisfaction should be motivational that lead to positive employment relationships and high levels of individual job performance. It was further suggested that job satisfaction could lead to two decisions by the person. First is to decide whether or not remain in the organization and the second is to decide to 
perform better. The decision to remain concerns the person's attendance and the longevity at work. In this sense, job satisfaction will influence absenteeism. A satisfied employee may likely have more regular attendance than a dissatisfied employee. On the other hand, job satisfaction will also affect turnover or decision to leave the organisation. In short, a dissatisfied employee is said to be more likely than a satisfied employee to quit his job.

\section{Internal Marketing}

The Internal Marketing (IM) concept was introduced in the early 1970s as a possible remedy to the problem of inconsistent service quality by providing employee with the required motivation and the desired level of satisfaction. The whole idea of this concept is to apply the external marketing approach towards internally. The organisation's employees are viewed as the "internal customers" and their jobs as "internal products" (Berry et al., 1976). The organisation works to satisfy the needs and wants of these "internal customers", while addressing the needs of the organisations (Berry, 1981). A motivated employee could perform better and similarly when they are "customer oriented and sales minded" (Gronroos, 1985). Putting all these earlier concepts together, Ahmed and Rafiq (2002) suggested that bearing in mind the weaknesses and strengths of definitions provided in the 25 years of literatures as well as the need to generalize the conceptualization beyond the service context to a more likely relevant area of application, IM was proposed to be defined as 'A planned effort using a marketing-like approach directed at motivating employees, for implementing and integrating organisational strategies towards customer orientation'. Today, marketing for the twenty first century regards IM as one of the four essential elements in holistic marketing along with relationship marketing, performance marketing and integrated marketing (Kotler \& Keller, 2006).

Internal Marketing is the key to external success. Greene et al. (1994) had further suggested that as the practices of marketing applied internally to the employees who serve external customers, employees would be more motivated as the employment offered to them meets their needs. Ahmed et al. (2003) had also suggested that IM affects business performance through organisational competencies for market-oriented behaviour, employee satisfaction and specific or individual competencies. The study by Huang and Rundle-Thiele (2014) that involved a review of over 200 literatures on IM in past 30 years was a comprehensive study. They found that IM is a threedimensional construct and tested on two settings of which one of it was the tourism and hospitality industry. The three IM dimensions suggested by Huang and Rundle-Thiele (2014) are internal market research, training and communication. Nevertheless, as this current study is attempting to investigate the effect of IM on employee turnover intention, it compared with Huang and Rundle-Thiele (2014) findings with the recommendation by AlBattat et al. (2014), AlBattat and Som (2013) towards reducing the turnover of employees in the Malaysian hospitality industry. Other than that, the findings by Kim (2014) whom had studied the turnover intention among newcomers in the travel industry in Korea and the proposed model of Internal Marketing by Rafiq and Ahmed (2000) of which theory this study is based are also considered. Based on these, four IM practices were selected: internal communication, reward system, training and working condition. The relationships are depicted in the research model shown in Figure 1.

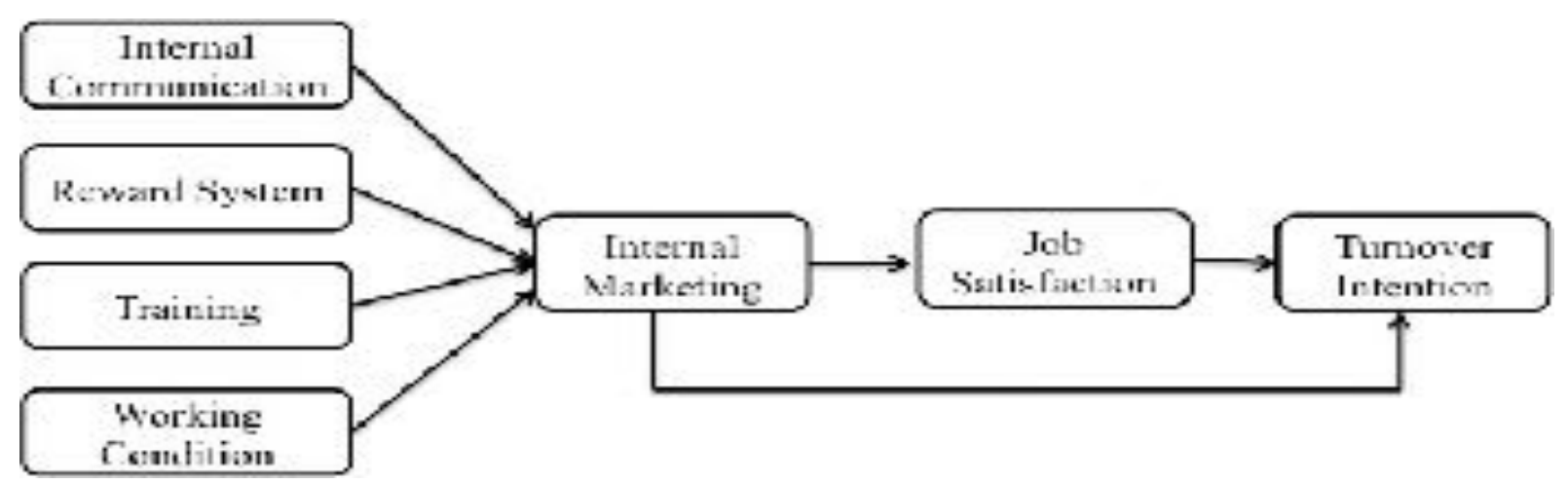

Figure 1. Research model 
In summary, it is expected that when an organization adopts internal marketing, the turnover intention of employees be reduced. Accordingly, internal marketing leads to job satisfaction and when an employee is satisfied, he or she will have positive attitudes towards his or her job and thus will retain the job. Therefore, based on these, the following four hypotheses are proposed.

Hypothesis 1. Internal Marketing is negatively correlated with turnover intention.

Hypothesis 2. Internal Marketing will increase employee's job satisfaction.

Hypothesis 3. The higher the employee's job satisfaction, the lower the employee's turnover intention.

Hypothesis 4. The relationship between internal marketing and employee turnover intention is mediated by job satisfaction.

\section{METHODOLOGY}

This study had adopted quantitative approach using survey questionnaire to collect feedback from 246 frontline employees of registered travel and tour agencies under the Malaysian Association Travel and Tour Agencies (MATTA) Sabah Chapter. The travel and tour agencies are spread around the major districts in the west coast and east coast of Sabah located over $500 \mathrm{~km}$ from Kota Kinabalu. The study utilised quota sampling techniques to determine the distribution of travel agencies to ensure representativeness of agencies from the various districts in Sabah. The respondents from each travel agency were conveniently chosen according to the pre-determined number of quota whereby the first available subject who met the inclusion criteria was selected. Research instrument used was based on Ahmed et al. (2003), Akroush et al. (2013), Huang and Rundle-Thiele (2014), Kim (2014).

Data were analysed using the Partial Least Square-Structural Equation Modeling (PLS-SEM) technique In order to accommodate both the internal marketing and each of its four dimensions (internal communication, training, reward system and work environment), the study utilised the reflective-formative higher order construct model. While the main construct internal marketing was formative second order construct, the four dimensions were reflective in the first order construct. Both job satisfaction and turnover intention were first order constructs and had used reflective measurements.

\section{RESULTS AND DISCUSSION Findings and Analysis}

The reflective first order measurement model of this study had satisfied the assessments of construct reliability and convergent validity with composite reliability of 0.912 (internal communication), 0.903 (rewards system), 0.954 (training), 0.851 (working condition), 0.946 (job satisfaction) and 0.923 (turnover intention). Fornell and Larcker (1981) criterion for discriminant validity were satisfied where results showed the constructs were different from each other. The formative second order measurement had also satisfied the assessments of collinearity and significance and relevance of formative model. The outer variance inflation factor (VIF) values for each of the formative constructs were below the threshold value of 3.3 (Diamantopoulos \& Siguaw 2006) with internal communication (1.721), reward system (2.442), training (1.979) and working condition (2.177). These results suggest that the formative constructs are distinct. The significance and relevance of outer weights was assessed by the use of bootstrapping of 5000 cases of subsamples had found internal communication, rewards system and working condition as significant formative constructs of internal marketing above the cut off level of p-value above 0.05 and tvalue above 1.96. The outer weights of training was found non-significant where the p-value was above the 0.05 cut off level. However, the outer loading was significant at 0.710 . Hair et al. (2013) provided that when the outer weight is non-significant but the outer loading is high (above 0.50), then the indicator should be interpreted as absolutely important but not as relatively important. Based on this, the training indicator is retained. Hair et al. (2013) suggested this method is known as absolute contribution and advised researchers should be aware of this method as dropping a formative indicator based on bootstrap outer weights assessment may result in poor content validity. 
Before the structural model was assessed, the test on collinearity was performed and found no collinearity issue in the inner model. The inner VIF value for each Internal Marketing to Turnover Intention and Job Satisfaction to Turnover Intention was 2.253. Diamantopoulos and Siguaw (2006) provided that VIF below 3.3 shows no collinearity issue. Table 1 shows the result of path coefficient assessment using bootstrapping procedures for the hypothesized relationships.

The relationship of Internal Marketing and Job Satisfaction, $\beta=0.746$, t-value $>1.96$ and $p$-value $<0.05$ is found significant. Likewise, the relationship of Job Satisfaction and Turnover intention, $\beta=-0.690$, $\mathrm{t}$-value $>1.96$ and $\mathrm{p}$-value $<0.05$ is also significant. The acceptable level of $\mathrm{p}$-value is below 0.05 and the t-value above 1.96. The significance of these relationships is supported by the result of the confidence interval bias shown in Table 2. When the confidence interval between lower and upper level percentile does not include zero, the relationship is significant (Hair et al., 2013). Hence, these conclude that $\mathrm{H} 2$ and $\mathrm{H} 3$ are supported.

Table 1. Path coefficient assessment

\begin{tabular}{|c|c|c|c|c|}
\hline & $\begin{array}{c}\text { Standard } \\
\text { Beta }(\boldsymbol{\beta})\end{array}$ & $\begin{array}{c}\text { Standard } \\
\text { Error }\end{array}$ & $\begin{array}{c}\mathbf{T} \\
\text { Value }\end{array}$ & $\begin{array}{c}\mathbf{P} \\
\text { Value }\end{array}$ \\
\hline Internal Marketing -> Job Satisfaction & 0.746 & 0.037 & 20.226 & 0.000 \\
\hline Internal Marketing -> Turnover Intention & -0.690 & 0.063 & 10.980 & 0.000 \\
\hline Job Satisfaction -> Turnover Intention & 0.023 & 0.080 & 0.2447 & 0.389 \\
\hline
\end{tabular}

Table 2. Confidence interval bias

\begin{tabular}{|c|c|c|c|c|c|}
\hline & $\begin{array}{c}\text { Original } \\
\text { Sample (O) }\end{array}$ & $\begin{array}{c}\text { Sample } \\
\text { Mean (M) }\end{array}$ & Bias & $\begin{array}{c}\mathbf{5 \%} \\
\text { (LL) }\end{array}$ & $\begin{array}{c}\text { 95\% } \\
\text { (UL) }\end{array}$ \\
\hline Internal Marketing -> Job Satisfaction & 0.746 & 0.747 & 0.002 & 0.677 & 0.798 \\
\hline $\begin{array}{c}\text { Internal Marketing -> Turnover } \\
\text { Intention }\end{array}$ & -0.690 & -0.688 & 0.002 & -0.800 & -0.595 \\
\hline Job Satisfaction -> Turnover Intention & 0.023 & 0.017 & -0.005 & -0.101 & 0.164 \\
\hline
\end{tabular}

To test the mediating effect of job satisfaction, the two-step approach by Hair et al. (2013) using bootstrapping procedure was adopted. First step addresses the significance of the indirect effect to know the presence of mediator and the second step addresses the significance of the direct effect to determine the type of mediation. Table 3 shows the result of the indirect effect. The indirect effect of internal marketing on turnover intention is significant at $\beta=-0.512$, $\mathrm{t}$-value $>1.96$ and $\mathrm{p}$ value $<0.05$. This indirect effect results shows the presence of mediation. 
Table 3. Indirect effect

\begin{tabular}{|c|c|c|c|c|}
\hline & $\begin{array}{c}\text { Direct Effect } \\
(\boldsymbol{\beta})\end{array}$ & $\begin{array}{c}\text { Standard } \\
\text { Error }\end{array}$ & $\begin{array}{c}\text { T } \\
\text { Statistics }\end{array}$ & P Values \\
\hline Internal Marketing -> Job Satisfaction & -0.512 & 0.062 & 8.312 & 0.000 \\
\hline $\begin{array}{c}\text { Internal Marketing -> Turnover } \\
\text { Intention }\end{array}$ & & & & \\
\hline Job Satisfaction -> Turnover Intention & & & & \\
\hline
\end{tabular}

The type of mediation is determined by the results of the direct effect. Table 1 shows the direct effect relationship between internal marketing and turnover intention as non-significant positive result with p-value above 0.05 and t-value below 1.96. This result suggests the mediation type is full mediation (Hair et al., 2013). Based on this result, H4 that proposed the relationship between internal marketing and employee turnover intention is mediated by job satisfaction is supported. The total effects of the relationships between IM and turnover intention shows a mean of -0.486 and significant with $\mathrm{t}$-value of 8.601 and $\mathrm{p}$-value of 0.000 . Therefore, H1 that proposed IM negatively correlated with turnover intention is supported.

\section{Discussion and Implication}

The findings of this study support past studies (Chen \& Lin, 2013; Chang \& Chang, 2007; Chen \& Chang, 2008; Kuria et al., 2012; Joung et al., 2015) that internal marketing practices promote employee retention, thus reducing employee turnover through the creation of job satisfaction. This current study had confirmed that this concept is applicable to the frontline employees of the travel agencies and tour operators in Sabah. More specifically, this study had found that internal communication, training, reward system and working condition were among the practices that helped in creating the job satisfaction of these employees. This study had also supported the suggestions made by AlBattat et al. (2014), AlBattat and Som (2013) to the Malaysian hospitality stakeholders to recognize that poor working condition and low salaries will lead the employees to turnover and change job. The results of this study reflected the voice of the millennials who made the majority of $84.5 \%$ of the total respondents. Compensation might be the strongest single driver of employer choice for the millenials but it does not work in isolation (Deloitte, 2017). This study had proven this point whereby the four factors examined in this study formed Internal Marketing, and thus the reward system alone would not have worked to create job satisfaction of the employees. It was further reported in the Deloitte Report that when choosing between organizations offering similar financial incentives, other factors that include work/life balance, opportunities to progress, flexible working arrangements, one that gives a sense of meaning and training programs that support professional development. At the same time, the managers need to be prepared that generally millenials are not loyal.

Scholars such as Akroush et al. (2013), Martin et al. (2006), Kuria et al. (2012), Huang and RundleThiele (2014) found internal communication is an important element of internal marketing particularly in the tourism and hospitality industry. Communication between job functions and employees (Barnes et al., 2004; Tracey \& Hinkin, 2008) will promote better relationship and constant communication of such will provide job clarity and promote better understanding among staff. These are supported in the findings by Kim (2014) that suggest clarity of job distribution and justice of a job would decrease turnover intention in the travel agencies in Korea. Given that the respondents of this study were mostly millenials, the finding that internal communication positively affect the employees' job satisfaction was seen as most significant and timely information for the travel and tours operators. According to Konferry Institute (2015), their study concluded that the millennials demand to be heard and expect a fast career trajectory. They want clear direction and clarity in terms of objectives and expectations. 
Deloitte's study suggested that millennial are more likely to stay longer in the organization when they are most satisfied with their learning opportunities and professional development programs (Deloitte, 2017). Managers should focus in providing trainings that are supporting the career development of the employees. Most importantly, other than deciding what are the suitable training for the employees, the managers should also seek the employees' suggestion on what would likely be their training needs. It was noted in the earlier discussion that travel and tour agencies were mostly constrained in term of cost but employers could register as a member of the Human Resources Development Fund (HRDF), where they could be eligible to apply for training grants to cover major portions of costs of training for their employees. HRDF is a government mandated agent to catalyse the development of competent local workforce in the country. It manages the country's development fund as well as serves as a one-stop centre to provide human resource development solutions to Malaysian small medium enterprises. This study had found that job satisfaction plays a crucial role in employee retention. The findings that job satisfaction fully mediates the relationship between Internal Marketing and employee turnover intention shows maximum evidence that the relationship is indirect only. This current study had also provided an empirical support to the concept of Internal marketing that focuses in providing employee motivation and satisfaction.

\section{CONCLUSION}

Therefore, in order to reduce the problem of employee turnover especially dysfunctional voluntary turnover, the managers of travel agencies and tour operators are urged to practice internal marketing. The managers of these agencies would need to put particular attention on internal communication, reward system, work environment and training. These four factors worked well together and removing any one of these factors in the implementation may not necessarily work. This present study had adopted a quantitative approach to achieve the objectives of the study. Due to the nature of this approach, there are limitations to this study such as possibility of other unidentified factors that influence the turnover intention of the employees that could be explored. For instance, the effect of external causes was also not studied. This is also one of the limitations of this study. It is therefore recommended that future research should employ a qualitative approach. Researchers would be able to conduct a deeper analysis using qualitative study. Another limitation of the present study is its restricted generalizability to other states of Malaysia. The work culture of the people of Sabah differs from those in the other parts of Malaysia. In order to extend the generalizability of the findings of this study, it has to be replicated to other states in Malaysia.

\section{REFERENCES}

Ahmed, P. K., \& Rafiq, M. (2002). Internal Marketing: Tools and concepts for customer-focused management. Butterworth Heinemann.

Ahmed, P. K., Rafiq, M., \& Saad, N. M. (2003). Internal marketing and the mediating role of organisational competencies. European Journal of Marketing, 37(9), 1221-1241.

Akroush M. N., Abu-ElSamen A. A., Samawi G. A., \& Odetallah A. L. (2013). Internal marketing and service quality in restaurants. Marketing Intelligence and Planning, 31(4), 304-336.

AlBattat, A. R. \& Som, A. P. M. (2013). Employee dissatisfaction and turnover crises in the Malaysian hospitality industry. International Journal of Business and Management, 8(5), 62-71.

AlBattat, A. R., Som, A. P. M., \& Helalat, A. S. (2014). Higher dissatisfaction higher turnover in the hospitality industry. International Journal of Academic Research in Business and Social Science, 4(2), 45- 52 .

Barnes, B. R., Fox, M. T., \& Morris, D. S. (2004). Exploring the linkage between internal marketing, relationship marketing and service quality: A case study of a consulting organization. Total Quality Management, 15(5/6), 593-601.

Berry, L. L. (1981). The employee as customers. Journal of Retail Banking, 3(3), 8-25.

Berry, L. L., Hensel, J. S., \& Burke, M. C. (1976). Improving retailer capability for effective consumerism response. Journal of Retailing, 52(3), 3-14. 
Berry, L .L., \& Parasuraman, A. (1992). Services marketing starts from within. Marketing Management, 1(1), 24-34.

Brown, S., \& Peterson, R. (1993). Antecedents and consequences of salesperson job satisfaction: Meta-analysis and assessment of causal effects. Journal of Marketing Research, 30(1), 63-77.

Chang, C. S., \& Chang, H. H. (2007). Effects of internal marketing on nurse job satisfaction and organisational commitment: Example of medical centers in Southern Taiwan. Journal of Nursing Research, 15(4), 265-274.

Chen, Y. C., \& Chang, W. C. (2008). Modeling internal marketing and employee loyalty: A quantitative approach. Asian Social Science, 9(5), 99-109.

Chen, Y. C., \& Lin, S. (2013). Applying importance-performance analysis for improving internal marketing of hospital management in Taiwan. International Business Research, 6(4), 45-54.

Dalton, D. R., Krackhardt, D. M., \& Porter, L. W. (1981). Functional turnover: An empirical assessment. Journal of Applied Psychology, 66, 716-721.

Deloitte. (2017). The 2017 Deloitte Millennial Survey Apprehensive millennials: Seeking stability and opportunities in an uncertain world. https://www2.deloitte.com/content/dam/Deloitte/global/ Documents/About-Deloitte/gx-deloitte-millennial-survey-2017-executive-summary.pdf.

Diamantopoulos, A., \& Siguaw, J. A. (2006). Formative versus reflective indicators in organizational measure development: A comparison and empirical illustration. British Journal of Management, 17(4), 263-282.

Faldetta, G., Fasone, V., \& Provenzano, C. (2013). Turnover in the hospitality industry: Can reciprocity solve the problem. Revista de Turismo y Patrimonio Cultural, 11(4), 583-595.

Fornell, C., \& Larcker, D. F. (1981). Structural equation models with unobservable variables and measurement error: Algebra and statistics. Journal of Marketing Research, 382-388.

Greene, W. E., Walls, G. D., \& Schrest, L. J. (1994). Internal marketing: The key to external marketing success. Journal of Services Marketing, 8(4), 5-13.

Gronroos, C. (1985). Internal marketing: Theory and practice. In American Marketing Association's Services Conference Proceeding, pp. 41-47.

Hair, J. F., Ringle, C. M., \& Sarstedt, M. (2013). Partial least squares structural equation modeling: Rigorous applications, better results and higher acceptance. Long Range Planning, 46(1-2), 1-12.

Hoppock, R. (1935). Job satisfaction. Harper.

Huang, Y. T., \& Rundle-Thiele, S. (2014). The moderating effect of cultural congruence on the Internal Marketing practice and employee satisfaction relationship: An empirical examination of Australian and Taiwanese born tourism employees. Tourism Management, 42, 196-206.

Joung, H. W., Goh, B. K., Huffman, L., Yuan, J. J., \& Surles, J. (2015). Investigating relationships between internal marketing practices and employee organizational commitment in the foodservice industry. International Journal of Contemporary Hospitality Management, 27(7), 1618-1640.

Kim, $N$. (2014). Employee turnover intention among newcomers in travel industry. International Journal of Tourism Research, 16(1), 56-64.

Konferry Institute. (2015). Attracting and retaining millennials in the competitive hospitality sector. World Tourism Forum Lucerne, Konferry Institute.

Kotler, P., \& Keller, K. L. (2006). Marketing management. Prentice Hall.

Kuria, S., Alice, O., \& Wanderi, P. M. (2012). Assessment of causes of labour turnover in three and five star-rated hotels in Kenya. International Journal of Business and Social Science, 3(15), 311-317.

Locke, E. A. (1976). The nature and causes of job satisfaction. In Handbook of Industrial and Organizational Psychology. Rand McNally College Publishing, pp. 1297-1343.

Lombard, M. R., \& Steyn, T. F. J. (2015). Internal marketing in the travel agency industry in the Western Cape Province. Southern African Business Review, 11(3), 144-158.

Martin, A., Mactaggart, D., \& Bowden, J. (2006). The barriers to the recruitment and retention of supervisors/managers in the Scottish tourism industry. International Journal of Contemporary Hospitality Management, 18(5), 380-397.

Mobley, W. (1982). Employee turnover, causes, consequences, and control. Addison-Wesley.

Mobley, W. H. (1977). Intermediate linkages in the relationship between job satisfaction and employee turnover. Journal of Applied Psychology, 62, 237-240.

Rafiq, M., \& Ahmed, P. K. (2000). Advances in the internal marketing concept: definition, synthesis and extension. Journal of Services Marketing, 14(6), 449-462. 
Richardson, S., \& Butler, G. (2012). Attitudes of Malaysian tourism and hospitality students' towards a career in the industry. Asia Pacific Journal of Tourism Research, 17(3), 262-276.

Saridakis, G., \& Cooper, C. (2016). Research handbook on employee turnover. Edward Elgar Publishing.

Schermerhorn, H. O. (2008). Organizational behavior. Wiley.

Sims, W. J. (2007). Antecedents of labour turnover in Australian Alphine Resort. Journal of Human Resources in Hospitality and Tourism, 6(2), 1-26.

Spector, P. E. (1997). Job satisfaction: Application, assessment, causes, and consequences. Sage Publications.

Tracey, J. B., \& Hinkin, T. R. (2008). Contextual factors and cost profiles associated with employee turnover. Cornell Hospitality Quarterly, 49(1), 12-27. 